\title{
The World as an Ironist's Playground: Reflections on Józef Wittlin's The Salt of the Earth ${ }^{1}$
}

\begin{abstract}
This article tries to characterize irony in Józef Wittlin's The Salt of the Earth, also in reference to the author's other texts. The author refers to the most important twentieth century methodology of the study of irony as well as to the scholars who study Wittlin's work, including: D.S. Muecke, D. Sperber i D. Wilson, B. Alleman, W. Szturc, P. Łaguna oraz K. Jakowska, Z. Yurieff, and E. Wiegandt.

Here, irony is treated as the attitude of a worldview that formed in part due to the experience of World War I. Thanks to the ironic view of reality (which in the very text of The Salt of the Earth is evident, for example, at the stylistic level) the author succeeds in saving his own world of values, which in this way is subject to Bakhtinian carnivalization.
\end{abstract}

Keywords: Józef Wittlin, The Salt of the Earth, irony, experience of World War I

Much has been written about irony in many ways. As a figure of speech and a trope, it belongs to the field of rhetoric, while as a stylistic device it forms part of poetics. Meanwhile, it was also a characteristic attitude in philosophy. Irony was already discussed back in Socrates' times, and it was the subject of Cicero's, Quintilian's, and Kierkegaard's reflections; now, the topic has returned in contemporary research. Over the past several decades, this term has once more come to play a very important role in the vocabulary of scholars of literature, philosophers, and the representatives of various other disciplines in the humanities. ${ }^{2}$

1 Originally published in Konteksty Kultury 2011, vol. 7 (the Polish title: "W żywiole ironii... O bohaterach Soli ziemi Józefa Wittlina”).

2 Here, it is necessary to reference at least two scholars, Paul de Man and Richard Rorty. Jerzy Kmita mentions this state of affairs ("Konieczne serio ironisty" [in:] idem, Konieczne serio ironisty: o przeksztatcaniu się problemów filozoficznych w kulturoznawcze, Poznań 2007), as does Anna Walczuk: "[T] he sense of irony does not reside only in the province of literature, but it has also invaded different areas of high and low art and culture" (Irony as a Mode of Perception and Principle of Ordering Reality in the Novels of Muriel Spark, Kraków 2005, p. 11). Walczuk's book is divided into two parts. The first is a compact and interesting overview of the most important Western theories of irony; something like this seems indispensible here. 
In his excellent book Ironia romantyczna. Pojęcie, granice i poetyka ("Romantic Irony: The Concept, Limits, and Poetics"), Włodzimierz Szturc describes past struggles with this category. He explains the three most important forms of irony (Socratic, rhetoric, and romantic) in great detail, after which he seals his reflections with the following comment:

However, these three types of irony have one common part (...). What is common to them can be described with the aid of the category of pretending that one is someone else than what one claims to be; that one thinks something different than how it is expressed; and that the author writes in a completely different way than what is implied in the literal interpretation of a statement. They also share the category of a lack of gravity or, rather, an illusion, because the sharpness of the judgment 'yes or no' dissipates in irony, while a play between 'seriously' and 'not seriously' appears. ${ }^{3}$

Most scholars of Józef Wittlin's works emphasize the presence of manifestations of irony or, more broadly, ironicness in his writing. "No classification of irony, no list of hitherto used ironic techniques will allow researchers to immediately identify every ironic expression," D.S. Muecke notes. ${ }^{5}$ I would add that such a classification would not even allow for a more satisfying characterization of irony or of ironic traits. It seems to me, then, that in order to achieve such results one does not need theory, but above all one must have certain expertise, perhaps such that only a native speaker has with respect to a language. Dan Sperber and Deidre Wilson write in a similar tone. According to them, it is difficult to lay down the poetics of irony, as it is better to recognize it intuitively. They claim that considering certain sentences to be ironic results from using an anti-frastic definition of irony that in this way becomes confirmed. Thus this vicious circle closes. ${ }^{6}$

At this point, it is worth mentioning one more thing; namely, the relationship between irony and laughter. This is especially important when we reference the "brotherhood" of Niewiadomski and Švejk in Jaroslav Hašek's novel that lingers in the reader's consciousness. Agnieszka Doda notes:

The category of irony cannot be easily separated from the literary categories of laughter, humor, the grotesque, etc. In other words, it cannot be separated from

3 W. Szturc, Ironia romantyczna. Pojęcie, granice i poetycka, Warszawa 1992, p. 6.

4 See esp.: K. Jakowska, $Z$ dziejów ekspresjonizmu w Polsce. Wokót "Soli ziemi", Wrocław 1977; E. Wiegandt, "Wstęp” [in:] J. Wittlin, Sól ziemi, Wrocław 1991; Z. Yurieff, Józef Wittlin, trans. M. Szczubiałka, Warszawa 1997 (the English version: Z. Yurieff, Joseph Wittlin, New York 1973).

5 D.S. Muecke, "Ironia: podstawowe klasyfikacje," trans. G. Cendrowska [in:] Ironia, ed. M. Głowiński, Gdańsk 2002, p. 44.

6 See: D. Sperber, D. Wilson, "Irony and the Use-Mention Distinction" [in:] Radical Pragmatics, ed. P. Cole, New York 1981, p. 301. 
what we could call, to quote Bakhtin, the 'world actually experienced;' namely, carnivalization. However, if we were to permanently link up the category of irony with laughter, this topic could easily become trivialized. Thus I am once again referencing Bakhtin, because he used the category of 'internal carnivalization,' which is not necessarily expressed in laughter; it can instead be a record of tragedy precisely with a peculiar distance. ${ }^{7}$

That is how irony appears in the only part of Wittlin's Powieść o cierpliwym piechurze ("The Story of the Patient Foot Soldier") trilogy known to us. This conviction will guide the direction of my inquiries.

Beda Allemann writes that "the factor of irony seems tolerable and useful only when it expresses not the author's personal and arbitrary attitude, but some state of the world that a literary line orientated in such a way can therefore decisively help one to know." I am convinced that in The Salt of the Earth these two elements make up a whole, the foundation of which is what we can call the author's pacifist attitude ${ }^{9}$ or the attitude of love of one's neighbor, as well as the experience of World War I.

Józef Wittlin was a writer who vociferously opposed the harm that one person causes another and, more broadly, to all living beings. The Franciscan influence on his worldview is often noted. ${ }^{10} \mathrm{Wittlin}$, who was an ethnic Jew and a Christian by choice, was far ahead of his time in foregoing the Biblical instruction from the Book of Genesis to "fill the earth and subdue it" (Genesis 1: 28). Instead, the author of The Salt of the Earth affirmed that life should exist in harmony with the surrounding world, which in a certain way brought him closer to the philosophy and spirituality of the Far East. This is expressed in Wittlin's unique religiosity, which was far removed from the models and expectations demanded by his role as a writer or thinker. It seems that in religion he did not so much look for answers to complicated theological problems, ${ }^{11}$ but to questions about the path of one's life, about "how to live." This is expressed above all in his interest in the figure of St. Francis, the Poor Man of Assisi, but also in his neighbor. These ideals, as well as Wittlin's par excellence Europeanness - after all, he was an heir to the legacy of ancient Greece and Rome and Judeo-Christianity as well as a citizen

7 A. Doda, Ironia i ofiara, Poznań 2007, pp. 21-22.

8 B. Allemann, "O ironii jako kategorii literackiej," trans. M. Dramińska-Joczowa [in:] Ironia, op. cit., p. 40.

9 I use the term "pacifist" as the best term describing a certain attitude towards war and militarism. Wittlin himself presents his attitude towards this term in his essay Ze wspomnień bytego pacyfisty ("From the Memoirs of a Former Pacifist").

10 See, for example, Czesław Miłosz's very personal essay Mój Wittlin ("My Wittlin”), Dekada Literacka 2001, no. 5-6.

11 At the same time, I do not claim that Wittlin's work is free of these motifs. Perhaps they were most beautifully implemented in poetry, in poems such as Trwoga przed smiercia ("Fear of Death") or Ściśle osobiste ("Strictly Personal”). 
of the Austro-Hungarian Empire - perhaps had the greatest impact on his attitude towards the crime of war, which for him and his peers became the defining experience of their generation. ${ }^{12}$

Leonid Heretz writes: "On the level of high culture, the Great War represents the crisis of the modern faith in science and progress, and has been analyzed as such by numerous twentieth-century thinkers." ${ }^{13}$ For Wittlin, however, World War I above all meant the crumbling of faith in the order of the world. For me, this is evident in the construction of the presented reality as well as in the arrangement of episodes making up the plot of The Salt of the Earth. ${ }^{14}$ Let me quote a suggestive example. Those who are most responsible for the outbreak of war are those who will never find themselves in the middle of its domain. Those who are farthest away from it (intellectually or geographically) bear the consequences of the kings, the "manufacturers of corpses" 15 (P 50). Consequently, the stabilized existence of the ordinary person is prone to destruction. According to Piotr Łaguna:

Irony as an attitude is also an awareness marked by a sense of contrast, contradiction between the phenomena of the internal or external world of a given individual as well as a feeling of superiority on the part of the person who ironizes. At the same time, the contradiction made known by the individual is subordinated to a certain idea or view of the world and the human being. ${ }^{16}$

As we know, Wittlin subjugates such a vision of the world to the Christian love of one's neighbor. Such intellectual formation contrasted with war had to give rise to resistance, which for Wittlin manifested both in feeling the irony of fate and, later, in choosing irony as the mode of the world presented in the novel The Salt of the Earth. Piotr Łaguna says that the irony of fate is the deception of expectations by reality. In Wittlin's case, his expectations

12 See: I. Maciejewska, "Doświadczenie wielkiej wojny - Józef Wittlin” [in:] Poeci dwudziestolecia międzywojennego, ed. eadem, Warszawa 1982, vol. 2; Z. Starowieyska-Morstinowa, Ci których spotykatam ("Those I Met"), Kraków 1962; J. Prokop emphasizes that rebellion against the war remains the central topic of Wittlin's oeuvre ("Józef Wittlin” [in:] Obraz literatury polskiej XIX i XX wieku. Literatura polska w okresie międzywojennym, ed. J. Kądziela, J. Kwiatkowski, I. Wyczańska, vol. 2, Kraków 1979, p. 126).

13 L. Heretz, "The Great War and the Desintegration of the Traditional Peasant worldview In Józef Wittlin's Salt of the Earth" [in:] Between Lvov, New York and Ulysses' Ithaca: Józef Wittlin Poet Essayist Novelist, ed. A. Frajlich, New York 2001, p. 45: "At the level of high culture, World War I represents a crisis of the modernistic faith in science and progress, and that is how it was analyzed by numerous twentieth century thinkers."

14 L. Fryde even writes about constructing a specimen of reality, and not reality itself (“O prozie Wittlina” [in:] idem, Wybór pism krytycznych, ed. A. Biernacki, Warszawa 1966, p. 407).

15 J. Wittlin, Wybór poezji, Kraków 1998, p. 50.

16 P. Łaguna, Ironia jako postawa i jako wyraz (z zagadnień teoretycznych ironii), KrakówWrocław 1984, p. 25. 
have even become ruined, as the outbreak of war was in essence their negation. Wojciech Ligęza emphasizes that:

Whereas the poets of the Skamander Group and the Krakow Avant-Garde wanted to quickly close the wartime accounts; forget about the horrors; and make a defense for a new, wonderful, and manifold reality, Wittlin instead tenaciously returned to the painful experiences of World War I and the Polish-Ukrainian War of $1918-1919 .^{17}$

At this point, I would like to reference a longer quote from an essay by Hugo von Hofmannsthal titled: "The Irony of Things", in which he contemplates Novalis' words that "after a lost war, one should write only comedies." Here is a selected fragment:

The element proper to comedy is irony, and indeed nothing is better fitted than a war which ends disastrously to clarify for us that irony which governs all things on earth. Tragedy bestows on its hero, the individual, an artificial dignity: it makes of him a demi-god and raises him above the circumstances of bourgeois existence. If it shifts but half a step away from this unconscious but necessary tradition, it slips into the realm of comedy. How close to the latter even a play like Hamlet comes - but Hamlet himself remains a king and hero, though one whose very substance the irony of circumstances and self-irony already began to act like rays of sun on a snowman (...). Yet comedy proper sets its individuals in a thousand fold enmeshed relationship to the world, it sets everything in relation to everything else, the and thus places everything in a relationship of irony. That is precisely how the war functions which overwhelmed us all, and which we have not yet escaped today, indeed may not escape for another twenty years. It set everything in relation to everything, the apparently great to the apparently little, that which apparently conditions things, to a new, higher principle by which in turn it is conditioned, the heroic to the mechanical, the emotive to the financial, and so on ad infinitum. At first, when the war began, the hero was ironized by the trench-digger; the man who wanted to stand erect and attack, by the man who wielded a shovel and dug in; at the same time, the individual was ironized by the mass to the point where his self-respect was crushed; indeed, not just the individual but the organized mass also, the battalion, the regiment, the corps was ironized by the still greater and amorphous mass - that frightening and pitiable giant - by something intangible by which it felt controlled and impelled, and for which it is hard to find a name: let us call it the spirit of nations. Yet the moment came where these vast masses themselves, symbolically unified, were ironized by the momentary sway of certain individuals who had somehow got their hands on the levers of power by which this unwieldy whole could for

17 W. Ligęza, "Świadek czasów i wyznawca wiecznych wartości. O poezji Józefa Wittlina" [in:] idem, Jaśniejsze strony katastrofy, Kraków 2001, pp. 11-12. 
the moment be governed. Yet at the same time, they themselves were already subject to cross-currents of the most virulent, subversive irony: the irony of contrast within the great notional generalizations to which they paid lip-service when faced with that welter of stubborn facts with which they had to contend; the irony of the tool visavis the premature and wittingly untrue synthesis. (...)

In all of this we find ourselves totally within the element of comedy - or rather, within an element of such universal irony as no comedy on earth displays (...) However, it is quite clear that it is the vanquished to whom this ironic might of events is made manifest. Whoever has come to the bitter end of any cause, will see the blindfold drop from his eyes; he will attain clarity of vision and gain deeper insight almost like one who has gone before. ${ }^{18}$

Hofmannsthal wrote this text in 1921, three years after the war had ended. Here, we could note the irony of fate, as the author wrote that it would be difficult to recover from the war even within twenty years. However, when this time had passed, another world war broke out. Nonetheless, this is not what is most important. Hofmannsthal notes the same things that later would become components of Wittlin's creative vision. After all, in The Salt of the Earth we observe the unique entanglement, expounded by Hofmannsthal, of what is heroic and what is mundane and petty. The best realization of this conceptualization is Piotr Niewiadomski, a simple peasant who is suddenly drawn into the whirlwind of history. Consequently, over the several days during which conscription occurs, he becomes a subject belonging to the emperor. The quoted text also mentions the ironic juxtaposition of characters and groups. This is similar in The Salt of the Earth. On the one hand, there is Niewiadomski, someone lost and subjugated and created according to separate laws of reality. On the other, there is Bachmatiuk, who refines and creates his surrounding world; he is not even especially concerned with the Zeus of this Olympus, Emperor Franz Joseph I. Another motif in Wittlin's novel is the unmasking of the language of propaganda and the characteristic use of the plural form, which is expressed, for example, in the proverbial phrase "beloved peoples." Hofmansthal notes the same thing, the denotation of a cliché when confronted with reality. Wittlin could have felt defeated in this war. In a metaphorical sense, he did not participate in it under the banner of any state. Instead, his flag was the previously mentioned ideal of love of one's neighbor as well as faith in people, which at that time was greatly weakened and even contested. ${ }^{19}$

18 H. von Hofmannsthal, "The Irony of Things" [in:] idem, An Impossible Man, trans. A. Stillmark, Cambridge 2016, pp. 129-130.

19 Wittlin writes about himself in the third person: "In this war, he was an Austro-Hungarian infantryman from the fall of 1916 to the fall of 1918. Like most of his comrades, he felt no hatred towards his 'enemies,' which was how he was supposed to view Russians, Italians, Serbs, and Romanians. On the contrary, during the war he befriended Russian prisoners-of-war who performed the duties of nurses, often with great dedication, in Austrian field hospitals. They 
Zoya Yurieff claims that: "Irony seems to not only be a trait of the literary vision itself, but also a feature of the writer's attitude to the world." ${ }^{20}$ It appears that it cannot be different in Wittlin's case. If the experience of a catastrophe does not result in complete aversion, or even hatred, of the world (we know that Wittlin's Christian ideals did not change after the war; instead, they grew even deeper), it must result in embitterment. Most often, these are the properties of the bitter irony in The Salt of the Earth. While reading the novel, there are many times when we would like to burst out laughing. However, there are reasons why we interpret the presented scenes as more of a bitter pill, as laughter relegates the expression of distaste to the back burner. Wolfgang Kayser claims that "the grotesque is the world that has become foreign to us;" 21 in this case, it would seem, it would be easier to laugh. In the case of The Salt of the Earth, we know that the world presented is our world. When the novel was published in 1936, this reality was one that many readers vividly remembered from their own experiences. Using Bakhtinian categories, war could be treated as an element of the carnivalization of existence, as war is, in essence, the world amiss, one in which death, not life, is the overriding value. The experience of the world turned upside down becomes, above all, evidence of the arbitrariness of the reality in which one lives; it shows that there exists no inviolable foundation. ${ }^{22}$ Consequently, affirmation not infrequently turns into skepticism or, at least, is revealed in such a way. Wittlin constructs a reality one does not want to believe in or accept, but whose objective existence makes it impossible to do so.

The world becomes the playground of an ironist. Thus, irony is also a means of perceiving and describing a reality in which one does not lose faith in the rules governing the world and in potential moral laws that are imperative with respect to it, although one observes their arbitrariness, impermanence, instability, and momentariness. In this way, irony becomes a defense against nihilism, negation, and complete withdrawal. ${ }^{23}$ Thus, as Ludwik Fryde wrote:

showed great compassion with regards to their wounded or ill 'enemies"” ("Postscriptum do Soli ziemi po trzydziestu pięciu latach” [in:] idem, Sól ziemi, Warszawa 1979, p. 271).

20 Z. Yurieff, op. cit., p. 93.

21 W. Kayser, Próba określenia istoty groteskowości, trans. R. Handke, Pamiętnik Literacki 1979, vol. 4, p. 276.

22 This is in accordance with how the rules of carnival illustrate this: once a year, a jester sits on the royal throne. Naturally, we cannot speak of any regularity in the case of war.

23 P. Łaguna writes: "Most generally, we can say that the process of shaping the ironist's mental attitude moves from making one aware of the existing contradictions to the search for such a level of the primacy of the subject, which ensures distance from the object of irony. This gives irony itself the virtue of objectivity that is necessary for liberation from awareness of the oppositional situation, which becomes subordinated to the negated phenomena" (idem, op. cit., p. 40). 
There arise doubts as to if The Salt of the Earth is in reality pervaded with this love of man, with the noble humanism that critics wrote so much about. After all, Józef Wittlin approaches the naive Piotr Niewiadomski with clear but indulgent irony and he presents Father Makarucha's spiritual struggles in an ironic way. Meanwhile, on the other hand, by presenting the stationmaster as demonic, he knows how to penetrate his human weaknesses. The poet's skepticism and relativism seem instead to be a bitter wisdom that understands and forgives everything rather than Christian love of one's neighbor. ${ }^{24}$

Józef Wittlin was not only a writer of prose (an epicist ${ }^{25}$ ); he also wrote poetry and essays. ${ }^{26}$ It seems, however, that irony is most visible in his fiction. ${ }^{27} \mathrm{I}$ am inclined to say that, in reality, The Salt of the Earth is a creative outgrowth of Wittlin's essay writing, particularly one text: Wojna, pokój $i$ dusza poety ("War, Peace, and the Poet's Soul"). ${ }^{28}$ I am under the impression that the selection of irony as a stylistic and even ontological mode within the work of prose was most influenced by the author's conviction that he could say more thanks to such an attitude. I also perceive such an intuition in an essay by Kazimierz Wyka, who notes that Wittlin makes his readers read generalizations, and comments on events between the lines. ${ }^{29} \mathrm{He}$ creates a distinct world that is governed by its own laws and that casual observers (the readers) are allowed access to. The narrator explicates the rules of a cosmos constructed as such, which is not without significance for interpretation. At this point, there appears the possibility of conveying "additional," or superfluous, information that is difficult to directly verbalize. We can assume

24 L. Fryde, op. cit., p. 405.

25 Krzysztof Dybciak calls The Salt of the Earth a "Galician epic:" "Admittedly, Piotr Niewiadomski does not resemble a hero; however, his life is full of the experiences of an ancient protagonist. The universal war cuts through the existence of the community just as deeply as the Trojan War. The Salt of the Earth is an epic from another era, which is why grotesque presentations and moments of tremendous satire are so significant" " Sól ziem i głos Orfeusza (O Józefie Wittlinie)," Więź 1983, no. 7, p. 98). See also: Z. Kubiak, "Polski homeryda" [in:] J. Wittlin, Sól ziemi, Warszawa 1979.

26 At this point, it is worth mentioning Wittlin's great sense of responsibility for the word. There are more comments on this topic. See: S. Gawliński, "Hardy imperatyw," Tygiel Kultury 2003, no. 1-3 and S. Gębala, “Odpowiedzialność za słowo,” Ruch Literacki 1982, no. 2.

${ }^{27}$ There are many comments on the ironic dimension of Wittlin's poetry in, for example, J. Olejniczak's text "Między 'Pan jest literat' a 'jestem tylko pisarzem.' O powinnościach i zobowiązaniach literatury Józefa Wittlina" ("Between 'You Are a Man of Letters' and 'I Am Only a Writer:' On the Duties and Responsibilities in Józef Wittlin's Essays”), Prace Naukowe Uniwersytetu Śląskiego $w$ Katowicach, ed. I. Opacki, Katowice 1990; as well as the previously mentioned article by I. Maciejewska.

28 See: note on Józef Wittlin [in:] E. Wittlin-Lipton, From One Day to Another, Madrid 2011: "Raptus Europae is considered by many an outline for the continuation of The Salt of the Earth".

${ }^{29}$ K. Wyka, "Powieść o cierpliwym piechurze" [in:] idem, Stara szuflada, Kraków 1967, p. 163. 
that this becomes possible mainly thanks to the unique atmosphere, or aura, created by ironizing. Whether or not one wants this, here Wittlin falls into the "trap" of irony. We are never guaranteed that the ironic message will be interpreted as we would like, as we had planned, or that between the lines (using Kazimierz Wyka's suggestion) the meanings that had been intentionally placed there will really be recognized. ${ }^{30}$ The irony that Cyprian Kamil Norwid wrote is "the necessary shadow of being" is in control of the ironist. If Wittlin's aim in creating an ironic world in The Salt of the Earth was to present more information than he could in his essays, for example, then I am afraid the work does not achieve the desired result. For many readers, irony is a barrier that is difficult to overcome. A read of the novel stops at this point, going no further. The curtain of the show of meanings was never opened for many audiences. In this way, the ironic perception of reality and the ironic creation of meanings are prone to becoming obsolete.

The American philosopher Frederic Jameson interprets the meaning of a work of modernist expressionism, Edvard Munch's painting The Scream, in a similar way. This is how Krystyna Wilkoszewska presents Jameson's analysis:

This painting, which fully represents the philosophy and aesthetic of expression, can at the same time be interpreted as their breach and even as their deconstruction. Painting is a mute art and the artist's desire to express a scream, which is a sound, collides with the medium chosen by him for this aim. There is a great tension between the large, fear-stricken eyes of a person (in which we decipher fright and the need to scream) and the fact that the figure presented in the painting lacks ears. The shout of suffering and agony that rings out within the human soul is not audible and thus in this way the titular scream is simultaneously present in the painting and absent from it. ${ }^{31}$

The Salt of the Earth carries meanings that some will never decipher. Questions that intellectuals began to ask only after the Second World War (which was even crueler than the first) had been posed by Wittlin much earlier. ${ }^{32} \mathrm{Sim}-$ ilarly, as a result of some possession by irony, above all the irony of fate, while reading The Salt of the Earth, readers witness the novel - which for decades was not accessible to the Polish reader and was written as a warning, but had unfairly become forgotten or had faded into obscurity - deconstruct itself.

30 Ibidem, pp. 162-163.

31 K. Wilkoszewska, Wariacje na postmodernizm, Kraków 2000, pp. 101-102.

32 Wittlin writes about this war: "[W]ith its horrifying effects, the Second World War familiarized humanity with its shame and debasement and made it resistant to jolts that threatened the health of its soul" ("Postscriptum do Soli ziemi po 35 latach" [in:] idem, Sól ziemi, Warszawa 1979, p. 270). I also write about this in: "Pytanie o Wittlina - spojrzenie na całość w roku 2011" ("Questions about Wittlin: A Look at Everything in 2011”), Fraza 2011, no. 3-4. 
Unknown soldiers become the salt of the earth; their deaths are supposed to fertilize the soil on which future generations will be raised. In the Gospel according to Matthew, Jesus' disciples, who are to go into the world and preach His teachings, are called "the salt of the earth." Whereas Christ treats them as subjects, as those who have a very important task to fulfill, the emperor (because it seems that the author had him in mind if we consider the figure of the monarch, and in a figurative sense, any ruler who leads to war, to be the personification of the state) the soldiers are only cannon fodder and part of the army inventory. A title interpreted as such also takes on an ironic meaning.

"Irony is so essential that The Salt of the Earth should not only be considered to be a largely ironistic novel, but perhaps it can be considered to be a canonical work of ironistic literature." 33 Meanwhile, Wittlin should be considered to be someone who, thanks to the ironist's worldview, knows much more about human personalities and the world than others.

\section{Translated by Filip Mazurczak}

\section{Bibliography}

Allemann B., “O ironii jako kategorii literackiej,” trans. M. Dramińska-Joczowa [in:] Ironia, ed. M. Głowiński, Gdańsk 2002.

Doda A., Ironia i ofiara, Poznań 2007.

Dybciak K., “Sól ziemi i głos Orfeusza (O Józefie Wittlinie)," Więź 1983, no. 7.

Fryde L., "O prozie Wittlina” [in:] idem, Wybór pism krytycznych, ed. A. Biernacki, Warszawa 1966.

Gawliński S., "Hardy imperatyw," Tygiel Kultury 2003, no. 1-3.

Gębala S., "Odpowiedzialność za słowo,” Ruch Literacki 1982, no. 2.

Heretz L., "The Great War and the Desintegration of the Traditional Peasant Worldview in Józef Wittlin's Salt of the Earth" [in:] Between Lvov, New York and Ulysses' Ithaca: Jozef Wittlin Poet Essayist Novelist, ed. A. Frajlich, New York 2001.

Hofmannsthal H. von, “The Irony of Things" [in:] idem, An Impossible Man, trans. A. Stillmark, Cambridge 2016.

Jakowska K., Z dziejów ekspresjonizmu w Polsce. Wokót “Soli ziemi”, Wrocław 1977. Kmita J., "Konieczne serio ironisty" [in:] idem, Konieczne serio ironisty: o przeksztatcaniu się problemów filozoficznych w kulturoznawcze, Poznań 2007.

Kayser W., Próba określenia istoty groteskowości, trans. R. Handke, Pamiętnik Literacki 1979 , vol. 4.

Kubiak Z., "Polski homeryda” [in:] J. Wittlin, Sól ziemi, Warszawa 1979.

Ligęza W., "Świadek czasów i wyznawca wiecznych wartości. O poezji Józefa Wittlina” [in:] idem, Jaśniejsze strony katastrofy, Kraków 2001. 
Łaguna P., Ironia jako postawa i jako wyraz (z zagadnień teoretycznych ironii), Kraków-Wrocław 1984.

Maciejewska I., "Doświadczenie wielkiej wojny - Józef Wittlin” [in:] Poeci dwudziestolecia międzywojennego, vol. 2, ed. eadem, Warszawa 1982.

Miłosz Cz., "Mój Wittlin," Dekada Literacka 2001, no. 5-6.

Muecke D.S., "Ironia: podstawowe klasyfikacje," trans. G. Cendrowska [in:] Ironia, ed. M. Głowiński, Gdańsk 2002.

Olejniczak J., 'Między 'Pan jest literat' a 'jestem tylko pisarzem.' O powinnościach i zobowiązaniach literatury Józefa Wittlina)," Prace Naukowe Uniwersytetu Śląskiego $w$ Katowicach, ed. I. Opacki, Katowice 1990.

Prokop J., "Józef Wittlin" [in:] Obraz literatury polskiej XIX i XX wieku. Literatura polska w okresie międzywojennym, ed. J. Kądziela, J. Kwiatkowski, I. Wyczańska, vol. 2, Kraków 1979.

Sperber D., Wilson D., "Irony and the Use-Mention Distinction" [in:] Radical Pragmatics, ed. P. Cole, New York 1981.

Starowieyska-Morstinowa Z., Ci, których spotykatam, Kraków 1962.

Szturc W., Ironia romantyczna. Pojęcie, granice i poetycka, Warszawa 1992.

Walczuk A., Irony as a Mode of Perception and Principle of Ordering Reality in the Novels of Muriel Spark, Kraków 2005.

Wiegandt E., "Wstęp" [in:] J. Wittlin, Sól ziemi, Wrocław 1991.

Wilkoszewska K., Wariacje na postmodernizm, Kraków 2000.

Wittlin J., "Postscriptum do Soli ziemi po trzydziestu pięciu latach" [in:] idem, Sól ziemi, Warszawa 1979.

Wittlin J., Wybór poezji, Kraków 1998.

Wittlin-Lipton E., From One Day to Another, Madrid 2011.

Wocław W.S., "Pytanie o Wittlina - spojrzenie na całość w roku 2011," Fraza 2011, no. 3-4.

Wyka K., "Powieść o cierpliwym piechurze" [in:] idem, Stara szuflada, Kraków 1967.

Yurieff Z., Józef Wittlin, trans. M. Szczubiałka, Warszawa 1997 (the English version: Z. Yurieff, Joseph Wittlin, New York 1973). 